\title{
NOAA's National Marine Mammal LabORATORY
}

\author{
By Howard W. Braham
}

$\mathrm{T}$ HE National Marine Mammal Laboratory (NMML) was established in 1978 by the National Marine Fisheries Service (NMFS) to study marine mammals worldwide in order to meet international commitments and domestic legislation. Located at the National Oceanic and Atmospheric Administration's (NOAA) Sand Point facility along Lake Washington in Seattle, the NMML is a division of the Northwest and Alaska Fisheries Center (NWAFC) and is housed in $2,500 \mathrm{~m}^{2}$ of office and laboratory space, including a marine mammal library containing over 20,000 holdings.

The responsibility of the NMFS is to investigate fishery resources and protected species with the long-range goal to understand how marine ecosystems function. Research by the NMML addresses specific management problems and theoretical questions about the biology and ecology of marine mammals. For example, the NMML began to study the bowhead whale and Dall's porpoise in the late 1970 's because of concerns raised by the International Whaling Commission and International North Pacific Fisheries Commission about the status of these two species. Because of the lack of data on whether the take of bowheads by Alaskan Eskimos would cause the bowhead population to become extinct, pressure was placed on the U.S. Government to stop the hunt. NOAA policy supported the Eskimo request to allow the hunt to continue, but at a reduced level sanctioned by the International Whaling Commission.

Research on Dall's porpoise began in 1978 because of the incidental take of marine mammals and birds in Japan's billion-dollar high seas salmon fishery. Japan was allowed to continue fishing in U.S. waters in exchange for funding U.S. research to determine the effects of incidental take on Dall's porpoise. In 1987. the high seas salmon fishery was closed after successful litigation against the U.S. Government by conservation organizations and western

Howard W. Braham, National Marine Mammal Laboratory, NWAFC, NOAA, 7600 Sand Point Way N.E., Bldg. 4, Seattle, Washington 98115.
Alaskan fishing interests.

The NMML recently completed the first year of a five-year research plan that focuses on the new ecosystem initiative proposed by the NMFS as the basis of management. Studies in the plan are designed to monitor and describe the natural history and population dynamics of marine mammals associated with a specific management issue. The work is being carried out in the Antarctic, Arctic, Bering Sea, Gulf of Alaska, North Pacific High Seas and California Current ecosystems.

Four areas of specialized study have been identified as crucial:

- Fisheries conflicts and interactions. Studies address the questions: Why are some marine mammal species declining in Alaska while those along the west coast south of Alaska are increasing? What effect will these trends have on local and national fishing interests, or on the status of the affected marine mammal?

- Status of depleted and recovering species. Studies monitor changes in trends in abundance and determine the status of populations relative to historical levels and stock definition.

- Marine mammal oceanographic investigations. Studies investigate the influence of oceanographic processes on the distribution. behavior and life history of marine mammals.

- Ecosystem dynamics and assessments. Studies deal with population trends, productivity levels and integration of oceanographic and atmospheric data into population assessments and ecosystem modeling.

Specific long-term studies underway to meet identified research and management needs are:

- Population dynamics, life history strategies and effects of fisheries on northern fur seals and Steller sea lions in the Bering Sea and Gulf of Alaska.

- Community ecology and effects of El Niño warm water events on California sea lions, northern fur seals, elephant seals and harbor seals at San Miguel Island. California.

- Reproduction, feeding ecology and trends in abundance of Antarctic fur seals, elephant seals, crabeater seals and penguins of the Antarctic Peninsula.

- Incidental take of harbor porpoise, Dall's porpoise, northern furseals and other marine mammals in coastal and high seas fisheries in the North Pacific.

- The status and recovery of gray, bowhead and humpback whales relative to subsistence whaling, habitat use and industry activities along the Pacific coast. $\square$

\section{Nansen Remote Sensing Center, Bergen, Norway}

\author{
By Ola M. Johannessen
}

\section{$T$} (NRSC) is named after Fridtjof Nansen (1861-1930), the Norwegian arctic oceanographer, zoologist and diplomat who in 1922 was awarded the Nobel Peace Prize for his outstanding humanitarian work for the refugees from the first world war. The NRSC was initiated by Ola M. Johannessen at Geophysical Institute, University of Bergen and founded January 1, 1987. The center is affiliated with the University of Bergen, where the director of NRSC holds a chair in oceanography and remote sensing.

Nansen's scientific work started at the age of 20 , when he was offered the position as curator of the zoological collection at the Bergen Museum (1882-88). He defended his doctoral thesis in 1888 , and shortly afterwards he was leading the first successful expedition across the Greenland Ice Shelf. Returning from Greenland, he accepted the position as curator of the zoological collection at the University of Oslo, where he also began preparations for the first successful drift across the unexplored arctic ocean in the years 1893-96 with the specially built ship Fram. The scientific results from the Fram drift posed many 